УДК 82.161.2+82.111

https://doi.org/10.31548/philolog2021.03.036

\title{
INTERTEXTUALITY IN PRATCHETT'S NOVELS: TYPES, SUBTYPES, MEANS OF MANIFESTATION
}

\author{
T. V. DAVYDOVA, PhD in Philology, Senior Lecturer, \\ Sumy State Pedagogical University named after A. S. Makarenko \\ E-mail: tatiadavydova@i.ua \\ https://orcid.org/000-0001-5815-8503
}

\begin{abstract}
The research is concerned with the comprehensive intertextuality of $T$. Pratchett's "Discworld" - a cycle of fantasy, representing a multifaceted parody of the fantasy, detective, scientific, mythological, cinematographic, and other texts and genre. The purpose of the paper is to identify various types, subtypes and functions of intertextuality as well as the verbal means of its manifestation in texts under consideration. To achieve the purpose, the study applies the methods of intertextual, textual-interpretational, hyper-textual and stylistic analyses. The main findings are as follows. The Pratchett's novels encompass all known types of intertextuality: text-text, text-genre, and text - cultural context, including intertextuality references to the literary texts, to non-literary texts and discourses as well as to other semiotic systems, such as painting, sculpture, music, films, comics. Intertextuality and its conveying devices perform a set of different functions, including parodic, semantic, stylistic and structural-compositional. The most frequent sources of literary intertextuality in Pratchett's novels are references to the works of Shakespeare, Tolkien and other writers, as well as to ancient and archaic mythology, primarily ancient Greek, ancient Egyptian and Indian cosmology. Sometimes one allusion creates a special allegorical framework for another, more specific allusion, based on intermedial sources - films, cartoons and different types of art. The identified intertextuality devices include full quotations, paraphrased and humorously reinterpreted idiom-precedent phenomena, precedent names as well as the names of theories, games, computer programs, etc. The revealed markers of intertextuality can be both unchanged and modified, altered. In the wider context of the novels the intertextuality devices sometimes acquire new denotative or connotative meanings. In addition to intertextuality references the paper identified in Pratchett's Discoworld the means of hypertextuality and architextuality.
\end{abstract}

Keywords: intertextuality, Pratchett's "Discworld", functions, precedent phenomena, hypertextuality, architextuality.

Introduction. The comprehensive intertextuality of T. Pratchett's "Discworld" is due, first of all, to the fact that this cycle of fantasy is a multifaceted parody of the fantasy genre itself, as well as modern sociocultural realities, scientific texts, detectives, etc., which attracts numerous quotations, reminiscences direct quotations referring to various iconic products of civilization from archaic cosmogonic myths of different peoples - to the works of Shakespeare and modern Hollywood blockbusters. The writer himself calls such intertextual knowledge "white knowledge", based on universal cultural signs and focused on different cultures, different levels of background knowledge of different ethnic groups. Thus, Pratchett tries, albeit in a parody form (which is not always possible to decode, as the line between parody and a serious philosophical understanding of reality cannot always be found) to find something universal in the different - in genres, cultural realities, scientific research, life, finally, human experience, which is due to the extremely wide use of the author's means of intertextuality.

Thus, the relevance of this study is due to the lack of research, firstly, parody intertextuality, and secondly, Pratchett's texts, which, in our opinion, are a kind of transitional link between the paradigms of postmodernism and metamodernism.

Recent research and publications. The theoretical basis of the paper encompasses the study of intertextuality within the linguistic framework, which focus on its meaning-creating and constitutive functions in text, discourse and culture $[1 ; 3-7]$.

The paper is partially based on a fivecomponent typology of intertextuality developed by Genette, including 'intertextuality', which comprises (a) marked and unmarked quotations or the so-called 'plagiarisms', and allusions; (b) 'hypertextuality' as a type of relationship between a text and some earlier source text or texts. In this category Genette includes parody, which can be based on "short texts, lines of text bereft of the context, famous statements, proverbs" $[3$, p. $7-24]$ and constitute the genrecreating feature of Pratchett's novels; (c) 'paratextuality', i.e., titles, subtitles, chapter titles, prefaces, notes, etc. [4, p. 15]. To solve the problems of our research, it is important to distinguish between intertextuality in the narrow and broad sense, as well as between 'intertextuality proper' and 'facultative' intertextuality" $[4$, p. $20 ; 5$, p. $85-86]$ - considering

(C) T. V. Davydova

«International journal of philology» | «Міжнародний філологічний часопис» Vol. 12, № 3, 2021 
the significance in Pratchett's Discoworld the 'facultatively' decoded borrowings depending on the readers erudition, and intertextuality devices, which are based on the symbolic products of culture, not reducible to literary sources.

In its broad meaning intertextuality encompasses all kinds of references: to other literary texts, to non-literary texts and discourses and even to other semiotic systems, such as painting, sculpture, music, films, comics, etc. [5, p. 82].

The purpose of the article is to identify various types, subtypes and functions of intertextuality as well as the verbal means of its manifestation in the Pratchett's fantasy book series "Discoworld".

To achieve the aim, the paper relies on the methods of intertextual, textual-interpretational, hyper-textual and stylistic analyses. The data encompasses texts from Terry Pratchett novels combined into a fantasy book series Discoworld.

Results. Analysis of Pratchett's Discoworld identified almost all known types of intertextuality: text-text, text-genre (structural-architectural relationships, according to Genet) and text symbolic products of culture and civilization. The last vector of intertextuality is embodied in the Pratchett cycle by numerous references to cultural, historical, scientific, archaeological, biological fields of scientific knowledge, as well as to intermedia texts of films, cartoons, art, etc.

The first, most fully represented type of intertextuality encompasses allusions to the writings of Shakespeare, Tolkien, Vonnegut, Lovecraft, Herbert, as well as to ancient and archaic mythology.

In particular, the allusion associated with Renz, King of Lancre, evokes associations simultaneously with two Shakespearean characters, the ghost of Hamlet's murdered father and his uncle Claudius, stabbed to death: And, like most people since the dawn of time, he was now dead. He was in fact lying at the bottom of one of his own stairways in Lancre Castle, with a dagger in his back [4].

In Pratchett's fantastic texts, allusions to Shakespeare's works perform various functions parody, semantic (highlighting additional connotations associated with the character), stylistic (creating a special atmosphere of the Middle Ages) and even structural and compositional. In particular, a quotation from Shakespeare's Macbeth "As the cauldron bubbled an eldritch voice shrieked: 'When shall we three meet again? There was a pause. Finally, another voice said, in far more ordinary tones: 'Well, I can do next Tuesday" [4] begins both the Pratchett's Weirrd Sisters and the sourse text, which makes it possible to predict further meaning and plot developments in the target borrowing text by analogy with the original text. It is interesting to note that the title of Pratchett's novel "Wyrd Sisters" is also an allusion to Shakespeare's Macbeth ("MacBeth:
Saw you the Weïrd Sisters?") [15].

The second most frequent source of literary intertextuality, as shown by the analysis of the material, are references to ancient and archaic mythology, primarily ancient Greek and ancient Egyptian, as well as Indian cosmology.

In particular, all of the Discoworld books begin, with slight variations, with a detailed description of a giant turtle and four giant elephants, on whose backs the entire Discoworld universe rests: the Discworld, which is flat and rides on the back of four giant elephants who stand on the shell of the enormous star turtle Great A'Tuin, and which is bounded by a waterfall that cascades endlessly into space [12].

A recurring illusion based on Hindu myths of the world being carried or enclosed by either a tortoise, a serpent or an elephant fulfills several functions in Pratchett's novels. First, he introduces the fantasy cycle into the archaic semiosphere, creating on its basis one of the possible worlds. Secondly, the same beginning-allusion connects the possible worlds of numerous texts of the cycle into a single whole, which is built and exists according to the same laws.

That is, through an archaically-bound allusion, the semiotic spaces of the cycle's texts, different in storyline, heroes, chronotope, are separated from the real world and, at the same time, are combined with each other. In addition to the semiotic function of structuring the world, an allusion to archaic cosmology manifests itself as a means of creating meaning, as it "unfolds" into a detailed description of various scientific theories related to the structure of the Universe, to the biological characteristics of the Universe, reproduction of giant turtles, on which the worlds are based, etc.: The early astrozoologists (...) were able to bring back much information about the shape and nature of A'Tuin and the elephants but this did not resolve fundamental questions about the nature and purpose of the universe. For example, what was Atuin's actual sex? This vital question, said the Astrozoologists with mounting authority, would not be answered until a larger and more powerful gantry was constructed for a deep-space vessel [11].

Thus, with the help of modifications of the allusion, Pratchett achieves a humorous effect, building a parallel parody chain of stories aimed at ridiculing modern society in which a kind of cult of science has been formed. In addition, the allusion to Indian mythology becomes a special allegorical structure to involve another intermedial simile-based allusion, relating in particular to films and TV series:

Then it comes into view overhead, bigger than the most unpleasantly-armed starcruiser in the imagination of a three-ring-filmmaker: a turtle, ten thousand miles 15 long [10] (an allusion to George Lucas' Star Wars movie).

A large body of Pratchett's intertextuality is

(C) T. V. Davydova

«International journal of philology» | «Міжнародний філологічний часопис» Vol. 12, № 3, 2021 
constituted by allusion to ancient Egyptian and Greek mythological texts. Such devices are almost never marked as they are identified in an implicit or altered and paraphrased form. In particular, the precedent name Necrotelicomnicon in "Some may talk of the Necrotelicomnicon with its pages made of ancient lizard skin" [13] is the modified Necronomicon, designating the ancient Egyptian book of the dead. The insertion of 'telicom' gives the precedent name additional humorous and parody connotations - a parody of the fantastic worlds of Tolkien and other authors of "high fantasy", as well as of Pratchett's own world, Discoworld, without boundaries between science and magic. Due to a stem 'telicom' Necrotelicomnicon becomes not only a book about communicating with the dead, but also their telephone directory.

Pratchett's intertextuality devices are structurally and functionally diverse and include:

(a) full quotations: They're looking at you, baby," he said (words of one of the characters from the movie "Casablanca»); diamonds are a girl's best friend (a song title); In the beginning was the Word (Join 1.1);

(b) paraphrased idiom-precedent phenomena: It was almost as scary as if the cat had disappeared and the smile remained (allusion to the smile of the Cheshire cat), often a humorously reinterpreted: "I think, therefore, I am a hat"? - he guessed (an allusion to the famous saying by Rene Descartes);

(c) precedent names - both unchanged (What is the name of this place, sir?" said the wizard. The blacksmith shrugged. "Bad Ass," he said [10] - an allusion to the well-known title of the film, which is traditionally recognized as an idiom characteristic outside the context of the original text), or paraphrased, found in fiction or movies: Leonard of Quirm (allusion to the famous Renaissance artist Leonardo da Vinci); Havelock Vetinari (association with the House of Medici; medicine as semantic hyperonym to veterinary medicine); Giama Casanunda, World's second greatest lover (allusion to Giacomo Casanova - a famous Venetian adventurer, reputed for having many romantic conquests);

(d) unaltered names of theories, games, acquiring new denotative or connotative meanings in the context of novels:

from that fiery union new turtles would be born to carry a new pattern of worlds. This was known as the Big Bang hypothesis [11];

It was good thunderstorm country, up here in the Ramtop Mountains [10] (an allusion to a system variable in British home computers called Ramtop);

(e) Hypertextuality devices aimed at

\section{References}

1. Allen, G, (2011). Intertextuality. New parodying of one text by another - in particular, allusions to detective fiction - from the novels of Arthur Conan Doyle, to the television program "Dragnet" and the film "The Beverly Hills Cop":

"'He's got a motive,' said Nobby.

'Yes?'

'Yes. Hammerhock was a dwarf.'

'That's not a motive.'

'It is for a troll. Anyway, if he didn't do that, he probably did something. There's plenty of evidence against him.'

Like what?' said Angua.

He's a troll.' [9] (allusions to the Western system of law and order become in Pratchett's trxts a means of effective satire on racial prejudice);

(i) architextuality devices, primarely providying a genre association between phantasy texts. In particular, the world of Disk can be seen as a parody of Tolkien's Middle-earth. Pratchett rethinks Tolkien's fantastic landscape, joining it to the realities of the Discworld. A significant part of allusions in Pratchett's novels is occupied by allusions to archetypal images, motives, plot moves. This is especially true of allusions to Techno Fantasy, where science and magic exist in parallel or transform into each other.

Demonologist. Midden Lane, Pseudopolis. Next door to the tannery," said Thursley hopefully [8].

He had hoped to spend his twilight years completing his seven-volume treatise on Some Little Known Aspects of Kuian Rain-making Rituals, which were an ideal subject for academic study in his opinion since the rituals only ever worked in $\mathrm{Ku}$ [8].

Conclusions and discussion. The major finding of the paper is that the Pratchett's novels encompass all known types of intertextuality: texttext, text-genre and text - cultural context, which perform parodic, semantic, stylistic and structuralcompositional functions. The most frequent source of literary intertextuality is references to the works of Shakespeare, Tolkien and other writers, as well as to ancient and archaic mythology, primarily ancient Greek, ancient Egyptian and Indian cosmology. Sometimes one allusion creates a special allegorical framework for another, more specific allusion, based on intermedial sources - films, cartoons and different types of art. The identified intertextuality devices include full quotations, paraphrased and humorously reinterpreted idiom-precedent phenomena, precedent names - both unchanged and modified, unaltered names of theories, games, computer programs, acquiring new denotative or connotative meanings in the context of novels, means of hypertextuality and architextuality.

Critical Idiom. 2nd edition. London, New York: Routledge. 
2. Book of 1 John. Retrieved from: https://www.biblestudytools.com/1-john/.

3. Genette G. (1997). Palimpsests: literature in the second degree / transl. Ch. Newman, C. Doubinsky. Lincoln, NE : University of Nebraska Press.

4. Majkiewicz, A. (2008): Intertekstualnosc implikacje dla teorii przekladu. PWN,Warszawa.

5. Nycz, R. (2000). Tekstowy świat. Poststrukturalizm a wiedza o literaturze, Warszawa, Kraków.

6. Orr, M. (2003). Intertextuality: Debates and Contexts. Cambridge: Polity Press, $256 \mathrm{p}$.

7. Plett, H. (1991). Intertextualities. In: Plett, H. ed. Intertextuality. New York: Walter de
Gruyter. P. 3-29.

8. Pratchett, Terry (2013). Eric. Harper.

9. Pratchett, Terry (2013). Guards! Guards! Harper.

10. Pratchett, Terry (2005). Equal Rites. Harper Perennial.

11. Pratchett Terry (2005). The colour of magic. Harper.

12. Pratchett, Terry (2001). Mort. Harper.

13. Pratchett, Terry (2000). The light fantastic. Harper. 277 p.

14. Pratchett, Terry (1988). Wyrd Sisters. Hartourch.

15. Shakespeare, W. Macbeth. Retrieved from: Macbeth: Entire Play (mit.edu).

\section{ІНТЕРТЕКСТУАЛЬНІСТЬ У РОМАНАХ ПРАТЧЕТТА: ТИПИ, ПІДТИПИ, ЗАСОБИ ВИРАЖЕННЯ Давидова Т. В.}

Анотація. Дослідження присвячене вивченню всеосяжної інтертекстуальності «Дискосвіту» T. Пратчетта - циклу фентезі, що представляє багатоаспектну пародію на френтезійні, детективні, наукові, міфологічні та інші тексти та жанри. Мета статті - ідентифрікація різних типів, підтипів та функцій інтертекстуальності, а також вербальних засобів їі маніфесттації. Для досягнення мети в дослідженні застосовуються методи інтертекстуального, текстовоінтерпретаційного, гіпертекстового та стилістичного аналізу. Основні висновки дослідження: Романи Пратчетта охоплюють усі відомі типи інтертекстуальності, такі як: текст - текст, текст - жанр та текст - культурний контекст. включаючи інтертекстуальні референції до літературних джерел, до нелітературних текстів та дискурсів, а також до інших семіотичних систем, таких як живопис, скульптура, музика, фільми, комікси тощо. Інтертекстуальні засоби у Пратчетта $m$ виконують сукупність різних ффункцій, включаючи пародійну, семантичну, стилістичну та структурно-композиційну. Найбільш частим джерелом літературної інтертекстуальності є посилання на твори В. Шекспіра, Дж. Р. Толкіна та інших письменників, а також на античну та архайчну міфологію, насамперед давньогрецьку, давньоєгипетську та індійську космологію. У дослідженні уперше визначений $i$ впроваджений у науковий обіг тип «форматної» (фрреймової) інтертекстуальності - коли певна алюзія створює алегоричний фоормат щодо інтерпретації решти алюзій - зазвичай інтермедіальних, із текстами-джерелами на основі фрільмів, мультфрільмів та різних видів мистецтва. Ідентифріковані у праці засоби інтертекстуальності включають: повні цитати; перефразовані та гумористично переосмислені прецедентні френомени; прецедентні імена, які можуть відтворюватися у незміненому вигляді і бути модифрікованими; назви теорій, ігор, комп'ютерних програм. Нерідко засоби інтертекстуальності набувають нових, відмінних від текстів-джерел, звідки вони запозичені, денотативних чи коннотативних значень у контексті романів. Крім інтертекстуальних рефреренцій, у романах Пратчетта ідентифріковані засоби гіпертекстуальності та архітекстуальності.

Ключові слова: інтертекстуальність, “Дискосвіт” Пратчетта, фрункції, прецедентні феномени, гіпертекстуальність, архітекстуальність. 